\title{
Presurgical Aspects of Nutrition in Tuberculous Spondylitis Patients
}

\author{
Farid Yudoyono, Rully H. Dahlan, Muhammad Z. Arifin, Achmad Adam \\ Department of Neurosurgery \\ Faculty of Medicine, Padjadjaran University - Hasan Sadikin Hospital \\ Jl. Pasteur 38, Bandung 40161, Indonesia \\ Email: faridspine@gmail.com
}

\begin{abstract}
Tuberculous spondylitis is a chronic infectious disease caused by Mycobacterium tuberculosis on the vertebral bone. Involved less than 3\% of all cases of TB, but the incidence varies around the world, and is associated with the quality of public health and socioeconomic conditions.The purpose of this study is to investigate the presurgical aspects of nutrition in patients with tuberculous spondylitis. A total of 39 consecutive patients between January 2011December 2012 were evaluated retrospectively. All patients diagnosed with spondylitis tuberculousis and treated with decompression, stabilization and fusion. All patients had been diagnosed with Spondylitis tuberculousis based on history taking, physical examination, laboratory finding and MRI. Our study showed that of all subjects, ten male patients and eight female patients had cervical $(n=1)$, thoracic $(n=15)$, and lumbar $(n=2)$ tuberculous spondylitis. The average age of the patients was $32.83 \pm 12.25$ (17-56) years old. The average preoperative body mass index (BMI) was $16.67 \pm 1.2 \mathrm{~kg} / \mathrm{m} 2$, albumin levels $3.23 \pm 0.21 \mathrm{~g} / \mathrm{dl}$, total protein level $6.2 \pm 0.34 \mathrm{~g} / \mathrm{dL}$. These were lower than normal value. We conclude that tuberculous spondylitis patients experience nutritional deficiencies presurgically and nutritional support should be considered pre-operatively.
\end{abstract}

Keywords: Mycobacterium tuberculosis, nutritional state, presurgical aspect, tuberculousspondylitis 


\title{
Aspek Nutrisi Prabedah pada Pasien Spondilitis Tuberkulosis
}

\author{
Farid Yudoyono, Rully H. Dahlan, Muhammad Z. Arifin, Achmad Adam \\ Departmen Ilmu Bedah Saraf \\ Fakultas Kedokteran Universitas Padjadjaran / RSUP. Dr. Hasan Sadikin Bandung \\ J1. Pasteur 38, Bandung 40161, Indonesia \\ Email: faridspine@gmail.com
}

\begin{abstract}
Abstrak
Spondilitis tuberkulosis merupakan infeksi kronis yang disebabkan oleh kuman spesifik yaitu Mycobacterium tuberculosis yang mengenai tulang belakang. Secara keseluruhan insidensinya di bawah 3\% dan berhubungan erat dengan kondisi kesehatan lingkungan dan sosial ekonomi di negara tersebut. Tujuan penelitian ini adalah untuk mengetahui status nutrisi prabedah pasien spondilitis TB. Secara retrospektif didapatkan total 39 pasien spondylitis TB dalam kurun waktu Januari 2011 sampai Desember 2012. Pada semua pasien dilakukan operasi laminektomi dekompresi, stabilisasi posterior dan fusi. Diagnosis ditegakkan berdasarkan anamnesis, pemeriksaan fisik, hasil laboratorium dan gambaran MRI tulang belakang. Data demografi dan hasil laboratorium dibandingkan dengan nilai normal. Dari penelitian ini didapatkan sepuluh pasien laki-laki dan delapan pasien perempuan dengan kelainan di tulang servikal $(n=1)$, torakal $(n=15)$, and lumbal $(n=2)$. Usia rata-rata pasien adalah $32,83 \pm 12,25(17$ 56) tahun. Rata-rata body mass index (BMI) prabedah adalah $16,67 \pm 1,2 \mathrm{~kg} / \mathrm{m}^{2}$, kadar albumin $3,23 \pm 0.21 \mathrm{~g} / \mathrm{dL}$, dan protein total $6,2 \pm 0,34 \mathrm{~g} / \mathrm{dL}$. Keseluruhannya di bawah nilai standar. Dari penelitian ini disimpulkan pasien spondylitis TB mengalami defisiensi nutrisi pada fase prabedah, dan diperlukan penanganan malnutrisi yang komprehensif sebelum dilakukan pembedahan.
\end{abstract}

Kata kunci: aspek prabedah, Mycobacterium tuberculosis, spondilitis tuberkulosis, status nutrisi 


\section{Research Article}

\section{Introduction}

Tuberculosis of the skeletal accounts for less than 3\% of all cases of tuberculosis and remains the cause of a higher morbidity and mortality in developing countries. Tuberculous spondylitis accounts more than half of the cases. ${ }^{1,2,3,4,5}$ Chronic state of infection in tuberculous spondylitisis is often associated with decreased immune system. In surgical candidate patients, poor nutritional status before surgery interferes with the wound healing process and has been associated with postoperative problems that increases morbidity and mortality. ${ }^{6,7}$

The prevalence of preoperative low nutrition state in patients with tuberculous spondylitisis is yet unknown. We consider this to be important as a prediction of patient's preoperative nutritional status that can decrease morbidity and mortality; hence, the number of disability can be reduced.

\section{Methods}

We retrospectively evaluated data for 39 patients who were treated with laminectomy decompression, stabilization, and fusion for tuberculous spondylitis at our institutions from January 2011- December 2012 and 18 (eighteen) patients were included in this study. Inclusion criteria of this research were patients aged 14-70 years with tuberculous spondylitis confirmed by history taking, physical examination, laboratory findings, and MRI image which showed abscess collection and expansion of granulation tissue adjacent to the vertebral body that is highly suggestive of tuberculous spondylitis. The subligamentous multiple contiguous bones paraspinal mass can be very well demonstrated by MRI. ${ }^{8,9,10}$ We collected blood specimens, Magnetic Resonance Imaging (MRI) data, nutritional state markers: body mass index, serum albumin level, total protein level, and hepatic enzymes.

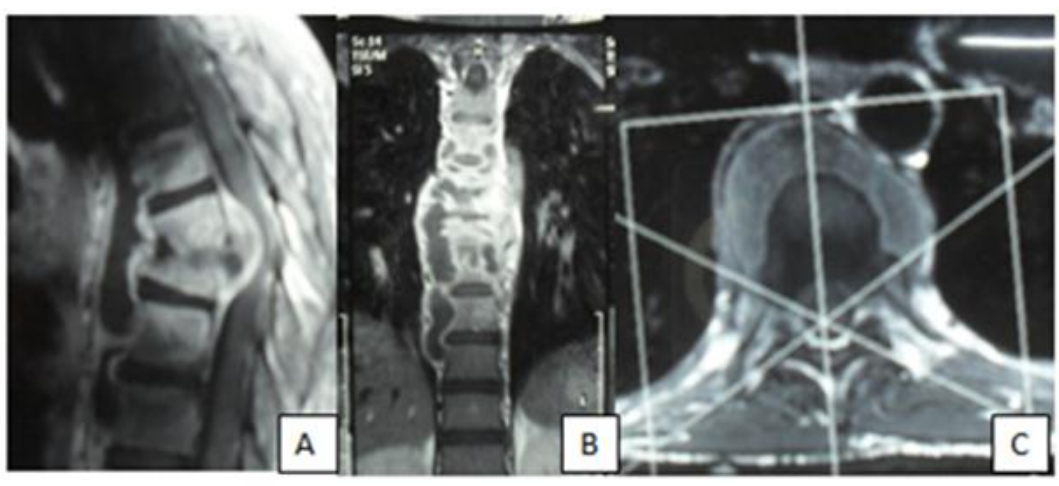

Figure 1 MRI Examination

Description

A) T1 Weighted sagittal MRI image sagittal cut showed subligamentous abcess.

B) T1 weighted coronal MR images showed multilevel paravertebral abcess.

C) T2 weighted axial MR images showed compression of spinal cord and paravertebral abcess. 


\section{Research Article}

\section{Results}

Thirty patients met the inclusion criterias, but 12 patients were excluded due to refusal to follow the surgery procedure; 5 patients refused surgery because of family reasons, 7 patients refused surgery and chose to follow the medication therapy. Final data was collected from 18 patients.

Table 1 Subjects Characteristics and Presurgical Nutritional Status

\begin{tabular}{|c|c|c|c|c|c|c|c|c|}
\hline Age & Sex & Spondylitis & Surgery & $\begin{array}{c}\text { BMI } \\
\left(\mathrm{Kg} / \mathrm{m}^{2}\right)\end{array}$ & $\begin{array}{l}\text { Albumin } \\
\text { (g/dL) }\end{array}$ & $\begin{array}{c}\text { Total } \\
\text { Protein } \\
(\mathrm{g} / \mathrm{dL})\end{array}$ & $\begin{array}{c}\text { SGOT } \\
\text { U/L) }\end{array}$ & $\begin{array}{l}\text { SGPT } \\
(\mathrm{U} / \mathrm{L})\end{array}$ \\
\hline 35 & $\mathrm{M}^{*}$ & $\mathrm{Th}^{* *} 4-5$ & $\begin{array}{l}\text { Lami decomp }{ }^{++}+ \\
\text {Posterior Stabilisation }\end{array}$ & 15.06 & 3.2 & 6.1 & 5 & 10 \\
\hline 39 & $\mathrm{M}$ & Th $11-12$ & $\begin{array}{l}\text { Lami decomp + } \\
\text { Posterior Stabilisation }\end{array}$ & 15.63 & 3.3 & 5.9 & 7 & 9 \\
\hline 45 & $\mathrm{M}$ & $C^{\S \S} 4-5-6$ & ACCF & 16.42 & 3.2 & 6.2 & 6 & 10 \\
\hline 23 & $\mathrm{M}$ & Th 7-8-9 & $\begin{array}{l}\text { Lami decomp }+ \\
\text { Posterior Stabilisation }\end{array}$ & 19.07 & 3.1 & 5.6 & 6 & 12 \\
\hline 19 & $\mathrm{~F}^{\S}$ & Th 3-4 & $\begin{array}{l}\text { Lami decomp }+ \\
\text { Posterior Stabilisation }\end{array}$ & 15.59 & 2.8 & 5.6 & 7 & 13 \\
\hline 25 & $\mathrm{~F}$ & Th12-L1 & $\begin{array}{l}\text { Lami decomp + } \\
\text { Posterior Stabilisation }\end{array}$ & 17.16 & 3.4 & 5.9 & 5 & 11 \\
\hline 43 & $\mathrm{~F}$ & Th 4-5-6 & $\begin{array}{l}\text { Lami decomp + } \\
\text { Posterior Stabilisation }\end{array}$ & 17.04 & 3.5 & 6 & 10 & 9 \\
\hline 56 & $\mathrm{M}$ & $\mathrm{L}^{\dagger} 2-3$ & $\begin{array}{l}\text { Lami decomp }+ \\
\text { Posterior Stabilisation }\end{array}$ & 17.40 & 3.1 & 6.2 & 14 & 15 \\
\hline 21 & $\mathrm{~F}$ & Th 4-5 & $\begin{array}{l}\text { Lami decomp + } \\
\text { Posterior Stabilisation }\end{array}$ & 17.51 & 3 & 6.4 & 9 & 20 \\
\hline 17 & $\mathrm{M}$ & Th $11-12$ & $\begin{array}{l}\text { Lami decomp + } \\
\text { Posterior Stabilisation }\end{array}$ & 15.79 & 2.9 & 6.5 & 12 & 21 \\
\hline 29 & $\mathrm{~F}$ & Th 7-8 & $\begin{array}{l}\text { Lami decomp + } \\
\text { Posterior Stabilisation }\end{array}$ & 17.90 & 3.3 & 6.4 & 13 & 19 \\
\hline 56 & $\mathrm{M}$ & Th 9-10-11 & $\begin{array}{l}\text { Lami decomp + } \\
\text { Posterior Stabilisation }\end{array}$ & 16.11 & 3.1 & 6.3 & 18 & 17 \\
\hline 40 & $\mathrm{~F}$ & Th 11-12 & $\begin{array}{l}\text { Lami decomp + } \\
\text { Posterior Stabilisation }\end{array}$ & 14.03 & 3.5 & 5.8 & 15 & 20 \\
\hline 33 & $\mathrm{~F}$ & Th 12-L1 & $\begin{array}{l}\text { Lami decomp }+ \\
\text { Posterior Stabilisation }\end{array}$ & 17.26 & 3.2 & 6.8 & 16 & 14 \\
\hline 39 & $\mathrm{~F}$ & Th 5-6-7 & $\begin{array}{l}\text { Lami decomp + } \\
\text { Posterior Stabilisation }\end{array}$ & 18.20 & 3.5 & 6.4 & 12 & 9 \\
\hline 31 & $\mathrm{M}$ & Th 5-6 & $\begin{array}{l}\text { Lami decomp + } \\
\text { Posterior Stabilisation }\end{array}$ & 16.51 & 3.4 & 6.5 & 13 & 10 \\
\hline 22 & $\mathrm{M}$ & Th $4-5$ & $\begin{array}{l}\text { Lami decomp }+ \\
\text { Posterior Stabilisation }\end{array}$ & 16.53 & 3.2 & 6.6 & 17 & 19 \\
\hline 18 & $\mathrm{M}$ & L 2-3 & $\begin{array}{l}\text { Lami decomp + } \\
\text { Posterior Stabilisation }\end{array}$ & 16.96 & 3.4 & 6.4 & 10 & 15 \\
\hline
\end{tabular}

${ }^{*}$ M:male; ${ }^{\S} \mathrm{F}$ :female; ${ }^{*} \mathrm{Th}$ :Thoracic; ${ }^{\S} \mathrm{C}: \mathrm{cervical} ;{ }^{\dagger} \mathrm{L}:$ lumbal; ${ }^{\dagger}$ Lamidecomp: laminectomy decompression

From the data we found that the average age of the patients was $32.83 \pm 12.25$ (17-56) years old, spondylitis were located mostly on thoracic spine 15 (83.3\%). To all subjects were performed decompression laminectomy and debridement followed by installation of posterior stabilization with pedicle screw which is due to instability and thoracic spine except one for anterior cervical corpectomy and fusion (Figure 2). Body mass index (BMI) averaged $16.67 \pm$ 
$1.2 \mathrm{~kg} / \mathrm{m}^{2}$ (14.03 to 19.07), 30\% below normal BMI. Albumin levels before surgery were $3.23 \pm$ $0.21 \mathrm{~g} / \mathrm{dL}$ ( 2.8 to $3,5 \mathrm{~g} / \mathrm{dL}), 24 \%$ below the normal value. Total protein levels were $6.2 \pm 0.34$ $\mathrm{g} / \mathrm{dL}, 3 \%$ below the normal value. SGOT levels were $10.83 \pm 4.33 \mathrm{U} / \mathrm{L}$ and SGPT levels were $14.06 \pm 4.33 \mathrm{U} / \mathrm{L}$; these were within normal limit.

\section{Table 2 Subject Average Values of Several Variables}

\begin{tabular}{lc}
\hline \multicolumn{1}{c}{ Variable } & Average value \\
\hline Age $($ years old $)$ & $32.83 \pm 12.25(17-56)$ \\
BMI $\left(\mathrm{kg} / \mathrm{m}^{2}\right)$ & $16.67 \pm 1.2$ \\
Albumin $(\mathrm{g} / \mathrm{dL})$ & $3.23 \pm 0.21$ \\
Total protein $(\mathrm{g} / \mathrm{dL})$ & $6.2 \pm 0.34$ \\
SGOT $(\mathrm{U} / \mathrm{L})$ & $10.83 \pm 4.33$ \\
SGPT $(\mathrm{U} / \mathrm{L})$ & $14.06 \pm 4.33$ \\
Spondylitis location & \\
$\quad$ Thoracic & 15 \\
Lumbal & 2 \\
Cervical & 1 \\
\hline
\end{tabular}

\section{Discussion}

Tuberculous spondylitisis is a frequent and the most dangerous form of skeletal tuberculosis, increasing in prevalence during the past decade in endemic regions, especially in patients with immune deficiency.Tuberculous spondylitis can occur in any age. Middle aged adults are the most frequently affected. ${ }^{11,12}$ In recent study, the most common age presenting with Tuberculous spondylitis is between 17 to $56(32.83 \pm 12.25)$ years old, which was different among countries. Low nutrition, poverty, and poor hygienic environment influence the spreading of disease. Males suffer more than females, and in recent study we found males were 1.25 times more than females and this is consistent with previous reports. ${ }^{12}$

In recent study, more than $80 \%$ of cases involved thoracic vertebra, which is also consistent with previous reports. This is accordance with the theory that it is easier to spread tuberculosis in thoracic spine from arterial way to subchondral region and valveless system of Batson's venous plexus in the vertebra that is allows two-way flow of blood correlated with pressure on intra abdominal and intra thoracic cavities or by lymphatic drainage to the paraaortic lymph node enabling the bacteria to spread. ${ }^{13,14,15}$

In recent study, BMI showed to be below normal, and this is consistent with the previous study. BMI lower than $18.5 \mathrm{~kg} / \mathrm{m}^{2}$ and lack of adequate weight gain are associated with an increased morbidity and mortality. ${ }^{2}, 16$ The reduced of food intake due to loss of appetite and physically debilitated caused by back pain aggravated by spinal instability and weight bearing and spinal cord and nerve root compression are the most devastating complication. ${ }^{15}$

In the previous study, tuberculosis patients with hypoalbuminemia were associated with increase mortality. Patients with serum albumin $<3.2 \mathrm{~g} / \mathrm{dL}$ had a six-month mortality above $20 \%$, indicating that these patients will need extra nutritional support to reduce the risk of mortality. ${ }^{17,18}$ 


\section{Research Article}

Recent study consistent with the previous study showed lower than normal value of albumin level $3.23 \pm 0.21 \mathrm{~g} / \mathrm{dL}$ (normal range 3.5-5.4 g/dL). Moreover, in recent study the total protein level $6.2 \pm 0.34 \mathrm{~g} / \mathrm{dL}$ was decreased to $3 \%$ of normal value. The hypoproteinemia and hypoalbuminemia may be due to poor nutritional intake of the patients. Given that low nutrition is correlated with decreased survival rate in tuberculous spondylitis patients, earlier reversal to improve nutrition could also have advantages for long term survival outcomes. ${ }^{2,19,20,21}$

The goal of surgery is liberating the spinal cord from compression by debridement and eradication the infection and achievement of a solid fusion by the installation of posterior stabilization with screw (Figure 3). ${ }^{22,23}$

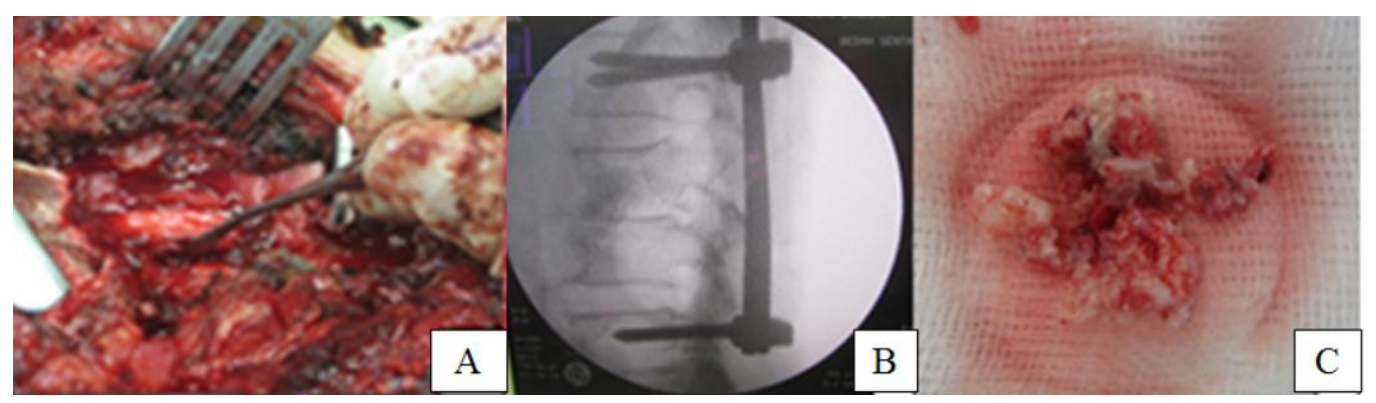

Figure 2 Intraoperative View

Description

A) Laminectomy decompression and spinal cord released after pus debridement.

B) flouroscopy following instalation of posterior stabilization.

C) Abcess formation.

Our study has a number of notable limitations, including those associated with its retrospective design. Clinical outcomes such as the Nutrition derived Outcome Risk Assessment (NORA) Score and the 36-Item Short-Form Health Survey and imaging were not evaluated because the long term recovery period after surgery and difficulty of patient in rural area to access to the health service center. However, despite these limitations, our study demonstrated the characteristics of presurgical nutritional state in Tuberculous spondylitis patients. To explain the nutritional and clinical outcome, further study is required.

\section{Conclusion}

We can conclude that patients with tuberculous spondylitis experience nutritional deficiencies presurgically and nutritional support should be considered preoperatively. This would be a clinical consideration for neurosurgeons, especially for those who work in developing countries, to evaluate the nutritional state for optimal clinical outcomes.

\section{Reference}

1. VaratharajahaS, Charlesa YP, Buy X, Walter A, Steiba JP. Update on the surgical management of Pott's disease. Orthop Traumatol Surg Res. 2014;100:233-9.

2. WHO. Nutritional care and support for patients with tuberculosis. Geneva: World Health Organization; 2013.

3. Rodriguez-Gomez M, Willisch A, Fernandez-Dominguez L, Lopez-Barros G,García-Porrúa C, Gonzalez-Gay MA. Tuberculous spondylitis: epidemiologic and clinical study in non-HIV patients from Northwest Spain. Clin Exp Rheumatol. 2002;20:327-3. 


\section{Research Article}

4. Trecarichi EM, Di Meco E, Mazzotta V, Fantoni M. Tuberculous spondylodiscitis: epidemiology, clinical features, treatment, and outcome. Eur Rev Med Pharmacol Sci. 2012;16(Suppl 2):58-72.

5 Bajwa GR. Evaluation of the role of MRI in spinal tuberculosis: a study of 60 cases. Pak J Med Sc. 2009:25(6): 944-7.

6 Moon MS.Tuberculosis of spine: current views in diagnosis and management. Asian Spine J. 2014; 8(1):97-111.

7 Cegielski JP, Arab L, Cornoni-Huntley J. Nutritional risk factors for tuberculosis among adults in the united states,1971-1992. Am J Epidemiol. 2012;176(5):409-22.

8 Khalequzzaman S, Hoque HW. Tuberculosis of spine Magnetic Resonance Imaging (MRI) evaluation of 42 cases. Medicine Today. 2012; 24(2):59-62.

9 Anley CM, Brandt AD, Dunn R. Magnetic Resonance Imaging findings in spinal tuberculosis: comparison of HIVpositive and negative patients. Indian J Orthop. 2012;46(2):186-90.

10 Hong SH, Choi JY, Lee JW, Kim NR, Choi JA, Kang HS.MR imaging assessment of the spine: infection or an imitation? Radiographics. 2009;29:599-612.

11 Moon MS, Kim SS, Lee BJ, Moon JL. Spinal tuberculosis in children: retrospective analysis of 124 patients. Indian J Orthop. 2012;46(2):150-8.

12 Benzagmout M, Boujraf S, Chakour K, El Faïz Chaou Mi. Pott's disease in children. Surg Neurol Int. 2011;2:1.

13 Ansari S, Rauniyar RK, Dhungel K, Lal Sah P, Chaudhary P, Ahmad K,Amanullah F. MR evaluation of spinal tuberculosis. Al Ameen J Med Sc. 2013;6(3):219-25.

14 Moorthy S, Prabhu NK. Spectrum of MR imaging findings in spinal tuberculosis. Ajr. 2002; 179:979-83.

15 Garg RK, Somvanshi DS. Spinal tuberculosis: a review. J Spinal Cord Med. 2011;34(5):440-54.

16 Sarin R, Vohra V, Sachdeva R, Sachdeva S.Magnitude of malnutrition amongst hospitalized TB patients.Lung India. 2011;28(3):231-2.

17 Alvarez-Uria G,Midde M, Pakam R, Naik PK. Diagnostic and prognostic value of serum albumin for tuberculosis in HIV infected patients eligible for antiretroviral therapy: datafrom an HIV cohort study in India. Bioimpacts. 2013;3(3):123-8.

18 Damburam A, Garbati M. A, Yusuph H. Serum proteins in health and in patients with pulmonary tuberculosis in Nigeria. J Infect Dis. Immun. 2012;4(2):16-9.

19 Gupta KB, Gupta R, Atreja A, Verma M, Vishvkarma.Tuberculousis and nutrition. Lung India. 2009; 1:9-16.

20 Paton NI, Chua YK, Earnest A, Be Chee C. Randomized controlled trial of nutritional supplementation in patients with newly diagnosed tuberculosis and wasting. Am J Clin Nutr. 2004;80:460-5.

21 Schwenk A, Macallan DC. Tuberculosis, malnutrition and wasting. Curr Opin Clin Nutr Metab Care. 2000; 3:285-91.

22 Do Brito JS, Tirado A, Fernandes P. Surgical treatment of spinal tuberculosis complicated with extensive abscess. Iowa Orthop J. 2014;34:129-36.

23 Oguz E, Sehirlioglu A, Altinmakas M, Ozturk C, Komurcu M, Solakoglu C, Vaccaro AR. A new classification and guide for surgical treatment of spinal tuberculosis. Int Orthop. 2008;32:127-33. 